\title{
Soft-bodied benthic algae in pristine Brazilian streams: from acid to karst ${ }^{1}$
}

\section{Bárbara Medeiros Fonseca ${ }^{2 *}$ (1) Lidia Mendes Feijó ${ }^{2}$ (D) and Luciana de Mendonça-Galvão²}

Received: March 18, 2019

Accepted: June 17, 2019

\begin{abstract}
This study evaluated soft-bodied benthic algae from seven streams located in protected areas of central Brazil (Parque Nacional de Brasília, Parque Nacional da Chapada dos Veadeiros and Parque Estadual de Terra Ronca), and related them to abiotic factors. We addressed the following questions: A) how algal community structure in Cerrado streams is influenced by the marked seasonality typical of the region; and B) how karst geology influences algal communities in Parque Estadual de Terra Ronca, as compared to streams in other Cerrado areas. Samples were collected between 2012 and 2013 from a single site in each stream, and upstream and downstream of caves present in Parque Estadual de Terra Ronca. Altogether, 159 taxa were recorded. Algal community structure varied significantly among sites, but not between seasons, despite relatively lower abundances during the rainy season, likely due to a negative influence of the faster currents in streams during this period. Some alkaliphilic species were observed only at sites near caves (e.g. the cyanobacterium Tolypothrix distorta), while acidophilic taxa were more frequent in the other streams (e.g. desmids and Cyanobacteria such as Scytonema caldarium, Hapalosiphon stuhlmannii and Stigonema ocellatum). We observed a rare green alga, Microthamnion kuetzingianum, and reported the cyanobacterium Rivularia aquatica for the first time in Brazil.
\end{abstract}

Keywords: abiotic variables, biodiversity, Cerrado, Cyanobacteria, lotic systems, periphyton, soft-bodied algae, pristine streams, Zygnematophyceae

\section{Introduction}

All over the world, anthropogenic influence on natural environments is increasing, and pristine aquatic systems are becoming scarce (Lindstrøm et al. 2004). Running waters unaffected by human impact are frequently restricted to areas protected by law (Fonseca et al. 2014; Fonseca \& Mendonça-Galvão 2014), and are thus very precious, as they can provide basic knowledge on biological reference conditions (Schneider 2015).

Soft-bodied benthic (SB) algae have been defined as non-diatom algae, including cyanobacteria, attached to substrata in lotic environments (Rott \& Schneider 2014).
Studies on SB algae in reference conditions have been mainly carried out in streams from temperate regions of North America (Thomas et al. 2015; Stancheva \& Sheath 2016) and northern Europe (Lindstrøm et al. 2004). In Brazil, this terminology has not been widely used; instead, the literature about benthic or periphytic algae in lotic systems mostly refers to diatoms (e.g. Salomoni et al. 2011; França et al. 2017) or macroalgal communities (e.g. Branco et al. 2001; 2008a; b; Necchi Jr. et al. 2008; Tonetto et al. 2015; 2018), and the majority of them are concentrated in the southeastern/southern regions. Microscopic attached algae from other taxonomical groups are less known, which may lead to underestimated numbers for general phycological diversity in such environments.

1 In memory of Sirlene Aparecida Felisberto

2 Laboratório de Biodiversidade Aquática, Universidade Católica de Brasília, 71966-700, Taguatinga, DF, Brazil

* Corresponding author: barbara.fonseca0603@gmail.com 
Soft-bodied benthic algae have already provided information for the development of ecological indexes used for monitoring ecological changes or spatial patterns (Schneider \& Lindstrøm 2009; 2011; Stancheva et al. 2013; Fetscher et al. 2014; Stancheva \& Sheath 2016). Although diatoms have been more studied under this approach and have often been considered the best indicator to reflect environmental conditions when compared to non-diatoms (Kelly et al. 2008), in some temperate countries the study of SB algae alongside diatoms is also mandatory for ecological quality analysis (Poikane et al. 2016).

Besides trophic status, other variables such as rainfall, current velocity and turbidity can be important environmental factors that influence periphytic and macroalgal communities in lotic environments, especially in nutrient-poor waters (Branco \& Necchi Jr. 1997; Branco et al. 2008b). Sometimes, despite regional variations, particular features of a stream can influence species richness on a local scale, promoting low inter-stream similarities and consequently increasing beta diversity (Rott \& Wehr 2016). Such spatial differences have been observed in several studies carried out in the southeastern/southern regions of Brazil (e.g. Branco et al. 2008b; 2009; Tonetto et al. 2015).

In central Brazil, a region covered by the Cerrado Domain (Brazilian savanna), seasonality is typically marked by the alternation between dry and rainy seasons (Silva et al. 2008), with consequences for both terrestrial and aquatic ecosystems (Fonseca \& Mendonça-Galvão 2014). Cerrado pristine waters generally have a slightly acidic $\mathrm{pH}$, with low electrical conductivity and low nutrient concentrations (Markewitz et al. 2006; Fonseca et al. 2014). However, some limestone outcrops with karst geology are also found in the region, generally belonging to the Brazilian sedimentary unit known as the Bambuí Group (Faquim et al. 2017), promoting alkaline waters and higher electrical conductivity (Righi-Cavallaro et al. 2010). Variation in these chemical variables ( $\mathrm{pH}$ and electrical conductivity) can result in marked differences in algal community structure (Mutinová et al. 2016).

The Parque Estadual de Terra Ronca(hereafter PETeR), one of the three protected areas considered in the present study, comprises the biggest South American cave complex, and its karst geology contrasts with the other two areas, Parque Nacional de Brasília(hereafter PNB) and Parque Nacional da Chapada dos Veadeiros(hereafter PNCV). These three protected areas are located in the core of the Cerrado Domain, at a distance of $160 \mathrm{~km}$ to $250 \mathrm{~km}$ from one another. Ecological studies on benthic or periphytic algae in lotic systems in central Brazil, especially unpolluted ones, are very scarce (e.g. França et al. 2017), despite their importance as primary producers and their strategic position at the bottom of trophic cascades (Necchi Jr. 2016).

For this study, our aim was to address two main questions: A) how algal community structure in Cerrado streams is influenced by the marked seasonality typical of the region; and B) how karst geology influences the algal communities in Parque Estadual de Terra Ronca, as compared to streams in other Cerrado areas. Special attention was also given to identifying rare taxa, or those that are characteristic of particular habitats.

\section{Materials and methods}

\section{Study area}

This study was carried out in seven pristine streams located in three protected areas in the Cerrado Domain, within the coordinates $13^{\circ}-15^{\circ} \mathrm{S} 46^{\circ}-48^{\circ} \mathrm{W}$ : Parque Nacional de Brasília, Parque Nacional da Chapada dos Veadeiros and Parque Estadual de Terra Ronca (Tab. 1, Fig. 1). The climate in the region is rainy tropical, i.e. "Aw" according to Köppen's classification (Alvares et al. 2014), marked by strong seasonality, with a dry/cool season from April to September (precipitation $30 \mathrm{~mm}$; air temperature $18^{\circ} \mathrm{C}$ ) and a rainy/warm season from October to March (precipitation $202 \mathrm{~mm}$; air temperature $29^{\circ} \mathrm{C}$ ). The mean annual air temperature is around $22^{\circ} \mathrm{C}$ (Silva et al. 2008).

The PNB covers 42,355 ha and is located in the Federal District of Brazil, within the large Brazilian hydrographic basin of Paraná. The other two protected areas are located in the State of Goiás, within the hydrographic basin of Tocantins-Araguaia. The PNCV spans an area of 64,727 ha, and the PETeR, 57,000 ha (ICMBIO 2016; SEMAD 2018).

Table 1. Geographical coordinates of nine sampling sites located in three protected areas in central Brazil. PNB = Parque Nacional de Brasília, PNCV = Parque Nacional da Chapada dos Veadeiros, PETeR = Parque Estadual de Terra Ronca. $S=$ substrata.

\begin{tabular}{|c|c|c|c|c|c|c|}
\hline Protected area & Stream & Code & Geographical coordinates & Altitude (m) & Order & Description \\
\hline \multirow[t]{2}{*}{ PNB } & Bananal & B1 & $15^{\circ} 42^{\prime} 50.23^{\prime \prime S} 48^{\circ} 00^{\prime} 45.03^{\prime \prime} \mathrm{W}$ & 1082 & 2 & Shaded. S: leaf litter, macrophytes (Sphagnum), roots \\
\hline & Santa Maria & B2 & $15^{\circ} 41^{\prime} 46.10^{\prime \prime S} 48^{\circ} 01^{\prime} 37.50^{\prime \prime} \mathrm{W}$ & 1096 & 2 & Partially shaded; substrata: clay, sand, macrophytes \\
\hline \multirow[t]{2}{*}{$\mathrm{PNCV}$} & Córrego 1 & $\mathrm{C} 1$ & $14^{\circ} 06^{\prime} 13.50^{\prime \prime} \mathrm{S} 47^{\circ} 42^{\prime} 19.50^{\prime \prime} \mathrm{W}$ & 1172 & 3 & $\begin{array}{l}\text { Partially shaded. S: sand, clay, pebbles, trunks, } \\
\text { leaf litter, macrophytes, roots }\end{array}$ \\
\hline & Estiva & $\mathrm{C} 2$ & $14^{\circ} 06^{\prime} 40.30^{\prime \prime} \mathrm{S} 47^{\circ} 44^{\prime} 02.20^{\prime \prime} \mathrm{W}$ & 1162 & 2 & Unshaded. S: macrophytes, pebbles, trunks, sand \\
\hline \multirow[t]{5}{*}{ PETeR } & São Vicente & $\mathrm{T} 1$ & $13^{\circ} 36^{\prime} 03.72^{\prime \prime S} 46^{\circ} 17^{\prime} 21.27^{\prime \prime} \mathrm{W}$ & 733 & 5 & Unshaded. S: sand, leaf litter \\
\hline & São Mateus S1 & $\mathrm{T} 2$ & $13^{\circ} 39^{\prime} 20.86^{\prime \prime S} 46^{\circ} 18^{\prime} 58.78^{\prime \prime} \mathrm{W}$ & 712 & 2 & Unshaded. S: pebbles, leaf litter, macrophytes, sand \\
\hline & São Mateus S2 & T3 & $13^{\circ} 41^{\prime} 47.78^{\prime \prime S} 46^{\circ} 25^{\prime} 43.91^{\prime \prime} \mathrm{W}$ & 512 & 3 & Unshaded. S: pebbles, sand, leaf litter, clay \\
\hline & Lapa S1 & $\mathrm{T} 4$ & $13^{\circ} 44^{\prime} 04.38^{\prime \prime S} 46^{\circ} 21^{\prime} 24.38^{\prime \prime} \mathrm{W}$ & 602 & 5 & Unshaded. S: sand, pebbles, leaf litter, trunks \\
\hline & Lapa S2 & T5 & $13^{\circ} 44^{\prime} 14.91^{\prime \prime S} 46^{\circ} 21^{\prime} 57.91^{\prime \prime} \mathrm{W}$ & 613 & 5 & Partially shaded. S: pebbles, sand, leaf litter \\
\hline
\end{tabular}



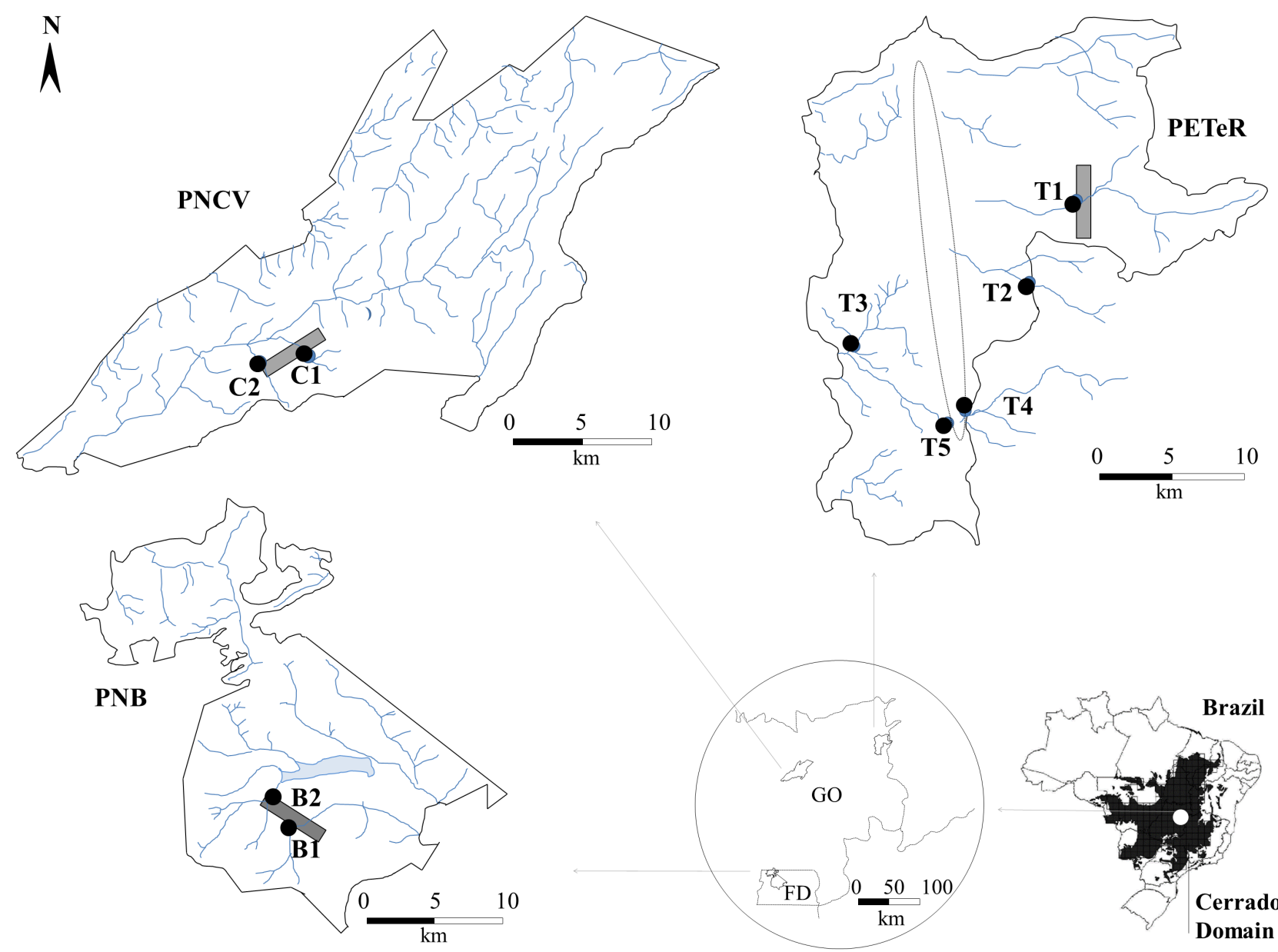

Figure 1. Location of the nine sampling sites within their respective protected area in the Cerrado Domain. PNB = Parque Nacional de Brasília, PNCV = Parque Nacional da Chapada dos Veadeiros, PETeR = Parque Estadual de Terra Ronca. Rectangles represent permanent grids $(5 \times 1 \mathrm{~km}$ ) for integrated inventories delimited by the ComCerrado Network; the dotted area in PETeR marks the location of caves. GO = State of Goiás; FD = Federal District of Brazil.

The approximate distances between the parks vary from $160 \mathrm{~km}$ (PNCV and PETeR) to $250 \mathrm{~km}$ (PNB and PETeR).

A permanent grid $(5 \times 1 \mathrm{~km})$ for integrated inventories had been previously delimited by the ComCerrado Network in each protected area, as part of a Brazilian research program (SISBIOTA/PPBio) whose main goal was to survey biodiversity in the Cerrado Domain, including different groups of organisms (e.g. França et al. 2017; Teixeira et al. 2017). Concerning aquatic ecosystems, every stream intersecting the aforementioned permanent grids was supposed to be sampled. So, in the present study, the following streams within the grids were examined: Bananal (B1) and Santa Maria (B2) in the PNB, Córrego 1 (C1) and Estiva (C2) in the PNCV, and São Vicente (T1) in the PETeR (Fig. 1). In the PETeR, besides São Vicente (T1), two other streams located outside the permanent grid were also sampled. The São Mateus and Lapa streams sink underground and then come up again downstream of caves and, considering this peculiarity, two sampling sites were located in each of them, upstream (sites T2 and T4) and downstream (sites T3 and T5) of their respective caves (Tab. 1). Altogether, nine sampling sites were considered in this study (one site per stream, except in the case of São Mateus and Lapa, where two sites were sampled).

\section{Fieldwork and laboratory analyses}

Sampling was conducted between 2012 and 2013, during the dry (July-August) and rainy (February-March) seasons, between 9 a.m. and 3 p.m. Each site was visited once in each season (exact sampling dates available as Tab. S1 in supplementary material). A $50 \mathrm{~m}$ transect was delimited on the stream edge, following its curves along the longitudinal axis. A suite of physical variables was measured for each site, including depth (maximum depth within the channel), wetted width and water velocity; for all variables, we considered the mean of six measures over the $50 \mathrm{~m}$ transect. For depth, a ruler was used; for width, a $20-\mathrm{m}$ 
tape; and for water velocity, a flowmeter model FLK1 (JDC Instruments, Switzerland). Geographical coordinates and altitude were measured with a Garmin eTrex Vista HCx GPS.

Subsurface water samples for abiotic analyses were collected in a midstream location. The following abiotic variables were measured in the field, using standard electrodes (Yellow Spring Instruments, USA): water temperature $\left({ }^{\circ} \mathrm{C}\right)$, dissolved oxygen (mg L-1), oxygen percentage saturation (\%), $\mathrm{pH}$ and electrical conductivity $(\mu \mathrm{S} \mathrm{cm}-1)$. Each variable was measured three times, also in a midstream location, and then the mean value for that site was calculated. Water samples for nutrient, solid and turbidity analyses were also collected and kept in a cooler until they were returned to the laboratory. Nitrate (N-NO3) (chromotropic acid and phenoldisulfonic acid methods), ammonium (N-NH4) (Nessler Method), soluble reactive phosphorus (SRP) (Stannous Chlorid Method) and silicate (Si) (Molybdosilicate Method) were analyzed after water filtration through combusted glass fiber filters with 0.7 $\mu \mathrm{m}$ pore size (Merck Millipore, Ireland). Unfiltered samples were used for total nitrogen (TN) and total phosphorus (TP) determinations (Valderrama 1981). Samples from PNB were processed in $24 \mathrm{~h}$ after the fieldwork. In the case of PNCV and PETeR, samples were preserved with sulfuric acid at $\mathrm{pH}<2$ (N-NO3, N-NH4, TP, TN) or kept under $4{ }^{\circ} \mathrm{C}$ (SRP and silicate), and processed after no more than five days. Nitrate was analyzed according to Taras (1950); the other nutrients, along with turbidity and solids, were analyzed according to Standard Methods (APHA 2005).

Benthic algae were sampled over the $50 \mathrm{~m}$ transect from the following substrata, whenever they were present: leaf litter, macrophytes, roots, trunks, pebbles, sand and clay. After an initial visual inspection of the transect, sampling of all possible substrata was carried out at both marginal and central positions and gathered within a tray. The number of substrata in each site varied from two (at T1) to seven (at C1) (Tab. 1). Macrophytes were squeezed and the other substrates were scraped with a toothbrush (leaf litter, roots, trunks, pebbles) using gentle jets of distilled water, or collected with the use of a syringe (sand and clay), and combined into a composite sample (150 mL). Samples were preserved in 3-5\% formaldehyde solution and deposited in the Laboratório de Biodiversidade Aquática, at the Universidade Católica de Brasília (collection number available as Tab. S2 in supplementary material).

We are aware of the weakness in making comparisons among sites without a measurement of the sampled area. However, this method was used because substrata were very heterogeneous among streams; all systems were being sampled for the first time, and the priority was to access as many SB species as possible, in order to capture the best picture of local biodiversity. Richness was then estimated and compared among sites, after imposing uniformity on the number of individuals counted. In each sample $(\mathrm{N}=$ 18 , i.e. nine sampling sites, two seasons), 400 individuals were counted in the course of a systematic inspection of the slides at 400x magnification, using an Olympus BX41 light microscope. In most of our samples, 400 individuals were found within the second inspected slide; however, in some of them densities were very low ( $<30$ individuals). In such cases (B2d, B2r, T1r and T5r; letters "d" and "r" represent dry and rainy seasons, respectively), at least four slides were inspected for each sample. This counting procedure was preceded by additional qualitative analyses at 100-1000x magnification, when at least four additional slides were evaluated for taxonomic identification using traditional literature (e.g. Förster 1964; Ramanathan 1964; Růžička 1981; Kadlubowska 1984; Lenzenweger 1996; Komárek \& Anagnostidis 2005; Komárek 2013). The number of species reported only in this qualitative assessment was insignificant, representing less than $2 \%$ of the total richness registered during the counting of 400 individuals. For filamentous green algae that cannot be identified to species level in their vegetative forms (e.g. Spirogyra, Mougeotia, Oedogonium), categories based on filamentous width and/or chloroplast features were used to distinguish morphospecies.

\section{Data analysis}

Multivariate descriptive analysis was carried out by applying Principal Component Analysis (PCA) to explore spatial and temporal variability, using a covariance matrix with data of eight abiotic variables transformed by their amplitude of variation ["ranging" $=(\mathrm{x}-\mathrm{minx}) /(\operatorname{maxx}-\min x)]$. The number of abiotic variables considered in the analysis was reduced after excluding the ones with missing values (problems with equipment or analytical analyses). This was the case of dissolved oxygen, nitrate, TN and turbidity. Abiotic variables (and also species richness) were compared between dry and rainy seasons using the non-parametric, paired difference, Wilcoxon signed rank test ( $\alpha=0.05$ ).

Species were classified into four categories based on their relative abundance: "rare" = RA $\leq 5 \%$; "common" $=5 \%<\mathrm{RA} \leq 40 \%$; "very common" $=40 \%<\mathrm{RA} \leq 70 \%$; "abundant" $=\mathrm{RA}>70 \%$. We used the Whittaker Index $(\beta \mathrm{w})$ to estimate beta diversity, dividing the overall richness (gamma diversity) by the average richness per sample (alpha diversity) $(\beta \mathrm{w}=(\gamma / \alpha)-1)(\mathrm{McC}$ une $\&$ Grace 2002). The one in the equation is subtracted to make zero beta diversity correspond to zero variation in species presence. NonMetric Multidimensional Scaling (NMDS) analysis was also performed in order to make inferences on similarity among sampling sites using the Dice Similarity Index, which is calculated on the presence/absence matrix (Hammer et al. 2001; Garraza et al. 2019). This index was chosen after some tests with other ones (e.g. Bray-Curtis) because it resulted in a lower stress value $(<0.20)$ (Clarke 1993). The samples with very low densities previously cited (B2d, B2r, $\mathrm{T} 1 \mathrm{r}$ and $\mathrm{T} 5 \mathrm{r}$ ) were excluded from this analysis because their 
presence also increased the NMDS stress to values above 0.20 . The abiotic variables $\mathrm{pH}$ and electrical conductivity were also considered in the NMDS. The SB community structure was then compared by means of a non-parametric ANOSIM test (Analysis of Similarity), with the Dice Index, run independently for the following null hypothesis: a) no difference between the distribution of taxa between rainy and dry seasons; b) no difference between the sites grouped by NMDS. Analyses were all run in the free software PAST ver. 2.17c (Hammer et al. 2001).

\section{Results}

\section{Abiotic data}

The majority of streams had slightly acidic water $(\mathrm{pH}$ $4.78-6.82$ ) and extremely low nutrient concentrations, usually under the detection limit (Tab. 2). Sites downstream of caves (T3 and T5) had higher $\mathrm{pH}$ (ranging from 7.25 to 7.82) and higher electrical conductivity (ranging from 38.3 to $263.4 \mu \mathrm{S} \mathrm{cm}-1$ ) when compared to the others. Site T4, while upstream of Lapa cave, had relatively high $\mathrm{pH}$ (7.70). We recorded $\mathrm{pH}=7.24$ and electrical conductivity $=717 \mu \mathrm{S}$ $\mathrm{cm}-1$ in water infiltrating through the inner wall of Lapa cave during the rainy season.

The first two PCA axes explained $66 \%$ of the variation in the abiotic data (Fig. 2). The main environmental gradient was represented by spatial differences among the protected areas, with samples from PETeR associated with lower nutrient concentrations and higher temperature. On the other hand, most samples from PNB were located on the opposite side of axis 1 . Samples from PNCV were on both sides of axis 1 ; stream $C 2$ was associated with relatively higher temperatures, while $\mathrm{C} 1$ grouped along with samples from PNB. On axis 1, the variables with the highest correlation were SRP $(r=0.86), \operatorname{TP}(r=0.84)$ and water temperature $(r$ $=-0.84)$. PCA axis 2 was primarily a $\mathrm{pH}$ gradient, with all sampling sites connected with caves plotting with higher $\mathrm{pH}(\mathrm{r}=0.79)$ and electrical conductivity $(\mathrm{r}=0.61)$.

When each abiotic variable was compared between rainy and dry seasons $(\mathrm{N}=9)$, there were significant differences for electrical conductivity ( $\mathrm{W}=41, p=0.03$ ), water velocity $(\mathrm{W}=27, p=0.04)$ and depth $(\mathrm{W}=40, p=0.04)$, all them with higher values during the rainy season.

\section{Soft-bodied benthic algae}

Altogether, 159 taxa were reported, consisting of 105 Zygnematophyceae, 30 Cyanobacteria, 13 Chlorophyceae, two Chrysophyceae, five Euglenophyceae, one Rhodophyceae, one Xanthophyceae, one Cryptophyceae, and one Dinophyceae (Tab. 3). Individuals of Chara sp. (Charophyceae) were observed in Lapa stream, downstream of Lapa cave (T5); as this macroscopic taxon was not counted in the slide inspection, it was not included in the species list.

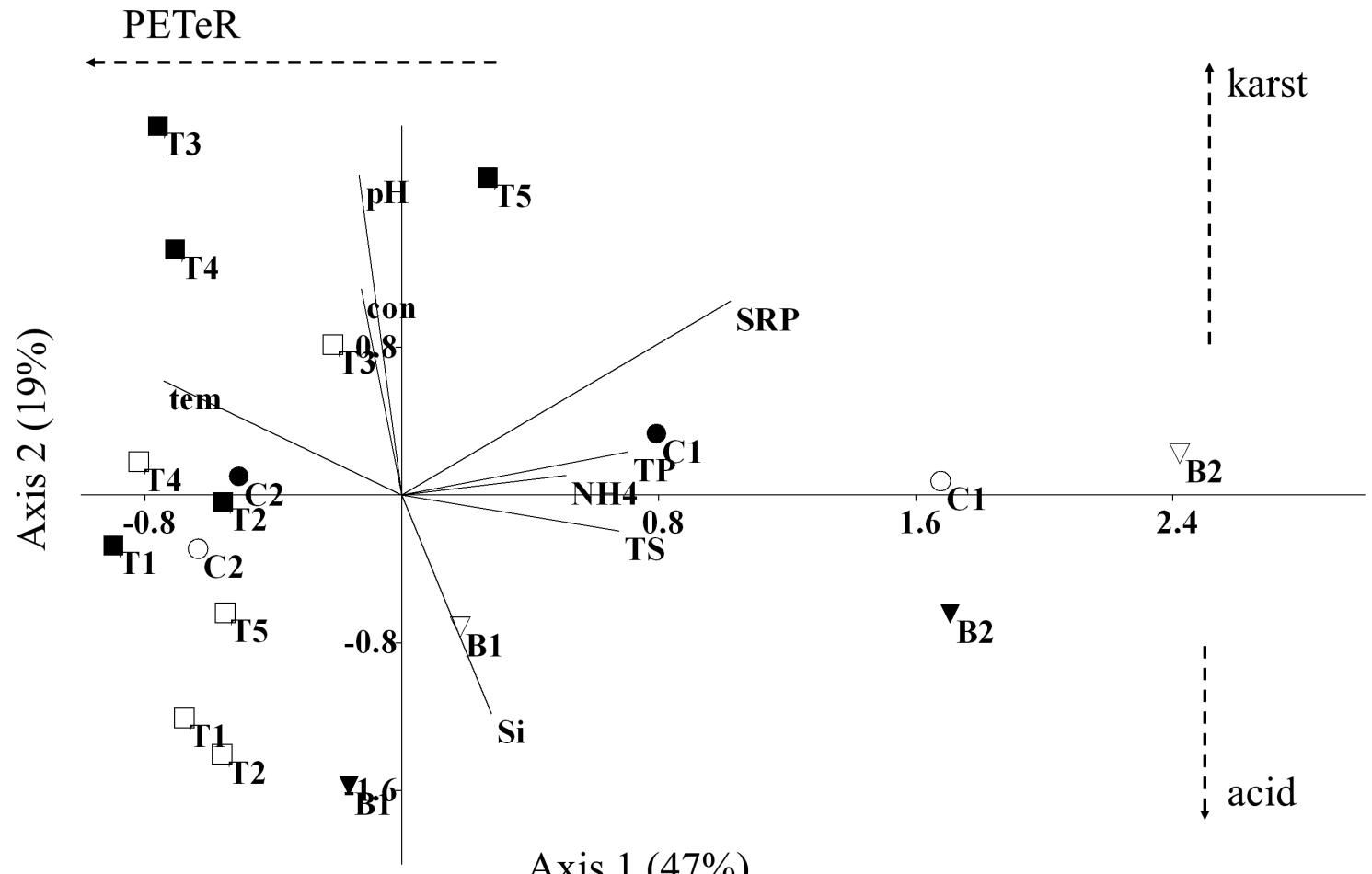

Figure 2. Principal Component Analysis (PCA) biplot with eight abiotic variables ( $\mathrm{pH}$, tem = temperature, con = electrical conductivity, $\mathrm{Si}=$ silicate, $\mathrm{NH} 4$ = ammonium, $\mathrm{TS}$ = total solids, $\mathrm{TP}=$ total phosphorus, $\mathrm{SRP}=$ soluble reactive phosphorus) and 18 sampling units (pristine stream sites in protected areas in central Brazil). Inverted triangles = Parque Nacional de Brasília; circles = Parque Nacional da Chapada dos Veadeiros; squares = Parque Estadual de Terra Ronca. Open and filled symbols represent dry and rainy seasons, respectively. 
Table 2. Abiotic variables in streams in three protected areas in central Brazil during dry and rainy seasons (2012-2013). PNB = Parque Nacional de Brasília, PNCV = Parque Nacional da Chapada dos Veadeiros, PETeR = Parque Estadual de Terra Ronca. ( ${ }^{*}=$ missing values).

\begin{tabular}{|c|c|c|c|c|c|c|c|c|c|c|c|c|c|c|c|c|c|c|}
\hline \multirow{3}{*}{ Variables } & \multicolumn{4}{|c|}{ PNB } & \multicolumn{4}{|c|}{ PNCV } & \multicolumn{10}{|c|}{ PETeR } \\
\hline & \multicolumn{2}{|c|}{ B1 } & \multicolumn{2}{|c|}{ B2 } & \multicolumn{2}{|c|}{ C1 } & \multicolumn{2}{|c|}{$\mathrm{C2}$} & \multicolumn{2}{|c|}{$\mathrm{T1}$} & \multicolumn{2}{|c|}{$\mathrm{T} 2$} & \multicolumn{2}{|c|}{ T3 } & \multicolumn{2}{|c|}{ T4 } & \multicolumn{2}{|c|}{ T5 } \\
\hline & dry & rainy & dry & rainy & dry & rainy & dry & rainy & dry & rainy & dry & rainy & dry & rainy & dry & rainy & dry & rainy \\
\hline Depth (m) & 0.51 & 0.54 & 0.5 & 0.64 & 0.51 & 0.95 & 0.52 & 0.78 & $>2$ & $>2$ & 0.59 & 0.57 & 0.48 & 0.57 & 0.72 & 0.72 & 0.52 & 0.42 \\
\hline Width (m) & 1.02 & 0.9 & 1.7 & 1.94 & 3.64 & 4.52 & 5.46 & 5.46 & 7.33 & 8.33 & 5.07 & 5.88 & 9.47 & 11.04 & 10.44 & 12.0 & 15.92 & 16.76 \\
\hline Water velocity $\left(\mathrm{m} \mathrm{s}^{-1}\right)$ & 0.1 & 0.0 & 0.4 & 0.4 & 0.1 & 0.5 & 0.1 & 0.5 & 0.6 & 0.6 & 0.6 & 0.9 & 0.3 & 0.5 & 0.6 & 1.0 & 1.1 & 1.9 \\
\hline Air temperature $\left({ }^{\circ} \mathrm{C}\right)$ & 35.1 & 30.7 & 26.7 & 26.4 & 28.5 & 26.5 & 27.2 & 28.4 & 27.8 & 24.0 & 36.7 & 25.5 & 32 & 27.5 & 29.8 & 25.0 & 28.3 & 24.8 \\
\hline Water temperature $\left({ }^{\circ} \mathrm{C}\right)$ & 20.2 & 21.5 & 17.9 & 21.4 & 18.0 & 21.9 & 25.0 & 22.1 & 24.2 & 23.8 & 24.4 & 25.1 & 24.2 & 25.7 & 26.4 & 26.4 & 24 & 24.3 \\
\hline $\mathrm{pH}$ & 5.57 & 5.19 & 6.6 & 5.19 & 6.65 & 6.53 & 6.54 & 6.82 & 4.78 & 6.13 & 5.73 & 5.72 & 7.25 & 7.47 & 7.53 & 7.82 & 7.35 & 7.37 \\
\hline Electrical conductivity $\left(\mu \mathrm{S} \mathrm{cm}^{-1}\right)$ & 5.4 & 13.5 & 4.2 & 23.6 & 13.0 & 8.6 & 3.0 & 4.8 & 7.5 & 8.4 & 4.5 & 5.5 & 124.4 & 236.3 & 8.1 & 26.4 & 13.4 & 38.3 \\
\hline Dissolved oxygen $\left(\mathrm{mg} \mathrm{L}^{-1}\right)$ & $*$ & 2.44 & $*$ & 4.56 & $*$ & 6.93 & $*$ & 7.60 & 6.48 & 6.32 & 6.63 & 6.51 & 7.26 & 7.02 & 6.96 & 7.82 & 7.81 & 7.91 \\
\hline Oxygen (\% saturation) & $*$ & 27.7 & $*$ & 51 & $*$ & 79 & $*$ & 84 & 76.9 & 75.0 & 76.8 & 78.6 & 85.7 & 86.2 & 86.7 & 94.8 & 91.3 & 94.8 \\
\hline Total phosphorus $\left(\mu g \mathrm{~L}^{-1}\right)$ & 4.0 & 3.0 & 9.0 & 7.0 & 7.0 & 6.0 & 2.0 & 3.0 & $<1$ & $<1$ & $<1$ & 2 & $<1$ & 2 & $<1$ & 3 & $<1$ & 4 \\
\hline $\mathrm{SRP}\left(\mathrm{P}-\mathrm{PO}_{4}^{-}\right)\left(\mu \mathrm{g} \mathrm{L}^{-1}\right)$ & 2.0 & $<1$ & 4.0 & 4.0 & 4.0 & 3.0 & $<1$ & 1.3 & $<1$ & $<1$ & $<1$ & 2 & $<1$ & 2 & $<1$ & 2.0 & $<1$ & 4.0 \\
\hline Ammonium $\left(\mathrm{N}-\mathrm{NH}_{4}{ }^{+}\right)\left(\mu \mathrm{g} \mathrm{L}^{-1}\right)$ & $<1$ & $<1$ & 4.0 & $<1$ & 2.0 & $<1$ & $<1$ & $<1$ & $<1$ & $<1$ & $<1$ & $<1$ & 1.4 & $<1$ & $<1$ & $<1$ & $<1$ & $<1$ \\
\hline Nitrate $\left(\mathrm{N}-\mathrm{NO}_{3}{ }^{-}\right)\left(\mu \mathrm{g} \mathrm{L}^{-1}\right)$ & 6.0 & 5.0 & 9.0 & 8.0 & 10.0 & 3.0 & 2.0 & 2.0 & $<1$ & 3.0 & * & 3.0 & * & 4.0 & * & 5.0 & * & 7.0 \\
\hline Total nitrogen $\left(\mu \mathrm{g} \mathrm{L}^{-1}\right)$ & 8.0 & 8.0 & 14.0 & 11.0 & 12.0 & 7.0 & 2.0 & 2.0 & $*$ & 2.0 & $*$ & 6.0 & * & 7.0 & $*$ & 6.0 & $*$ & 9.0 \\
\hline Turbidity (NTU) & 0.23 & 0.88 & 4.39 & 4.58 & 0.67 & 7.63 & 0.72 & 3.16 & $*$ & 1.02 & $*$ & 0.93 & $*$ & 1.42 & $*$ & 0.73 & * & 1.14 \\
\hline Total solids (mg L $\left.{ }^{-1}\right)$ & 4.0 & 7.0 & 16.0 & 22.0 & 8.0 & 13.2 & 9.0 & 0.9 & 0.3 & 1.7 & 0.3 & 2.0 & 6.2 & 3.0 & 0.1 & 1.0 & 0.7 & 1.0 \\
\hline Suspended solids $\left(\mathrm{mg} \mathrm{L}^{-1}\right)$ & 3.0 & 5.0 & 14.0 & 18.0 & 3.0 & 4.0 & 8.0 & 1.0 & $*$ & 2.0 & $*$ & 1.0 & $*$ & 1.0 & $*$ & 1.0 & $*$ & 1.0 \\
\hline Dissolved solids $\left(\mathrm{mg} \mathrm{L}^{-1}\right)$ & 1.0 & 2.1 & 2.0 & 2.4 & 5.0 & 3.6 & 1.0 & 1.0 & $*$ & 1.0 & $*$ & 1.0 & $*$ & 2.0 & $*$ & 1.0 & $*$ & 1.0 \\
\hline Silicate $\left(\mathrm{mg} \mathrm{L}^{-1}\right)$ & 1.066 & 1.893 & 1.801 & 2.181 & 2.179 & 1.015 & 1.123 & 0.613 & 1.074 & 0.478 & 2.682 & 0.478 & 1.141 & 0.677 & 1.893 & 0.603 & 3.078 & 0.582 \\
\hline
\end{tabular}

Species richness ranged from five (B2) to 61 (C2) (Tab. 3) and did not show a significant difference between rainy and dry seasons ( $W=37, p=0.08, N=9$ ) (Fig. 3 ). Considering the total of occurrences, $85 \%$ of the taxa were classified as "rare", contributing less than $5 \%$ of total abundance in their respective sample (Tab. 3). Some green algal taxa, notably Mougeotia and Spirogyra species, were classified as "very common".

The Whittaker Index $(\beta \mathrm{w})$ for beta diversity was 5.3. The NMDS revealed two groups of samples: group 1, formed by sites with low $\mathrm{pH}$ and low electrical conductivity (B1, C2, T1, $\mathrm{T} 2$ ); and group 2, with site $\mathrm{C} 1$ and the ones with relatively higher $\mathrm{pH}$ and electrical conductivity (T3, T4 and T5) (Fig. 4). The ANOSIM showed significant differences between groups 1 and $2(\mathrm{R}=0.70 ; p<0.001)$, but not between rainy and dry seasons ( $p>0.05$ ). Group 1 comprised sites located in the three protected areas. The cyanobacteria Scytonema caldarium and Hapalosiphon stuhlmannii were common in this group, especially in the sites with macrophytes as substrates (B1 and C2). Other exclusive taxa were the chlorophyte Microthamnion kuetzingianum (B1) and desmid species in the genera Micrasterias and Euastrum. Group 2 corresponded to sites with higher $\mathrm{pH}$ and electrical conductivity in Parque Estadual de Terra Ronca (T3, T4 and T5). The only exception was site $\mathrm{C} 1$. Although it had moderately acidic waters, it had some species in common with the other streams. Some cyanobacterial taxa were reported exclusively at $\mathrm{T} 3$, such as Lyngbya martensiana and Oscillatoria princeps (Tab. 3).

We highlight below some taxa of special importance, in general cited for the first time for the country or for central
Brazil. This was the case of the cyanobacteria Rivularia aquatica and Tolypothrix distorta and the chlorophyte Microthamnion kuetzingianum.

Rivularia aquatica was observed only in São Mateus stream (T2), upstream of its cave, at $\mathrm{pH}=5.5$ and electrical conductivity $=5.7 \mu \mathrm{S} \mathrm{cm}-1$ (mean values), during both dry and rainy seasons. It formed conspicuous olivegreen (sometimes darker) gelatinous hemispherical to spherical colonies, encrusted on pebbles, with a smooth slimy surface, up to $10 \mathrm{~mm}$. Trichomes were gradually attenuated towards ends, $8-9 \mu \mathrm{m}$ at the base, slightly constricted at cross-walls, attenuated into a long hair at the end, blue-green. Heterocytes were observed at the base of trichomes, spherical, solitary, and wider than trichomes.

Tolypothrix distorta was observed only in Lapa stream ( $\mathrm{T} 4$ and $\mathrm{T} 5$ ), at $\mathrm{pH}=7.6$ and electrical conductivity = $21.6 \mu \mathrm{S} \mathrm{cm}-1$ (mean values), during both dry and rainy seasons. Trichomes were cylindrical, slightly constricted at cell walls, width 6.9-7.6(8.6) $\mu \mathrm{m}$, length 3.6-5.7 $\mu \mathrm{m}$, bluegreen or olive-green. Heterocytes were spherical, 8.7-9.4 $\mu \mathrm{m}$. Filaments were $12-13 \mu \mathrm{m}$ (-44.5 when fasciculate), colorless or sometimes yellowish-brown.

Microthamnion kuetzingianum was observed only in Bananal stream (B1), at $\mathrm{pH}=5.4$ and electrical conductivity $=9.4 \mu \mathrm{S} \mathrm{cm}-1$ (mean values), during both dry and rainy seasons, associated with Sphagnum L. banks. Filaments were often densely and irregularly branched, branches spreading or slightly curved; cells $2.6 \mu \mathrm{m}$ wide, up to 40 $\mu \mathrm{m}$ long, cylindrical, each cell with parietal chloroplast, without pyrenoids. 

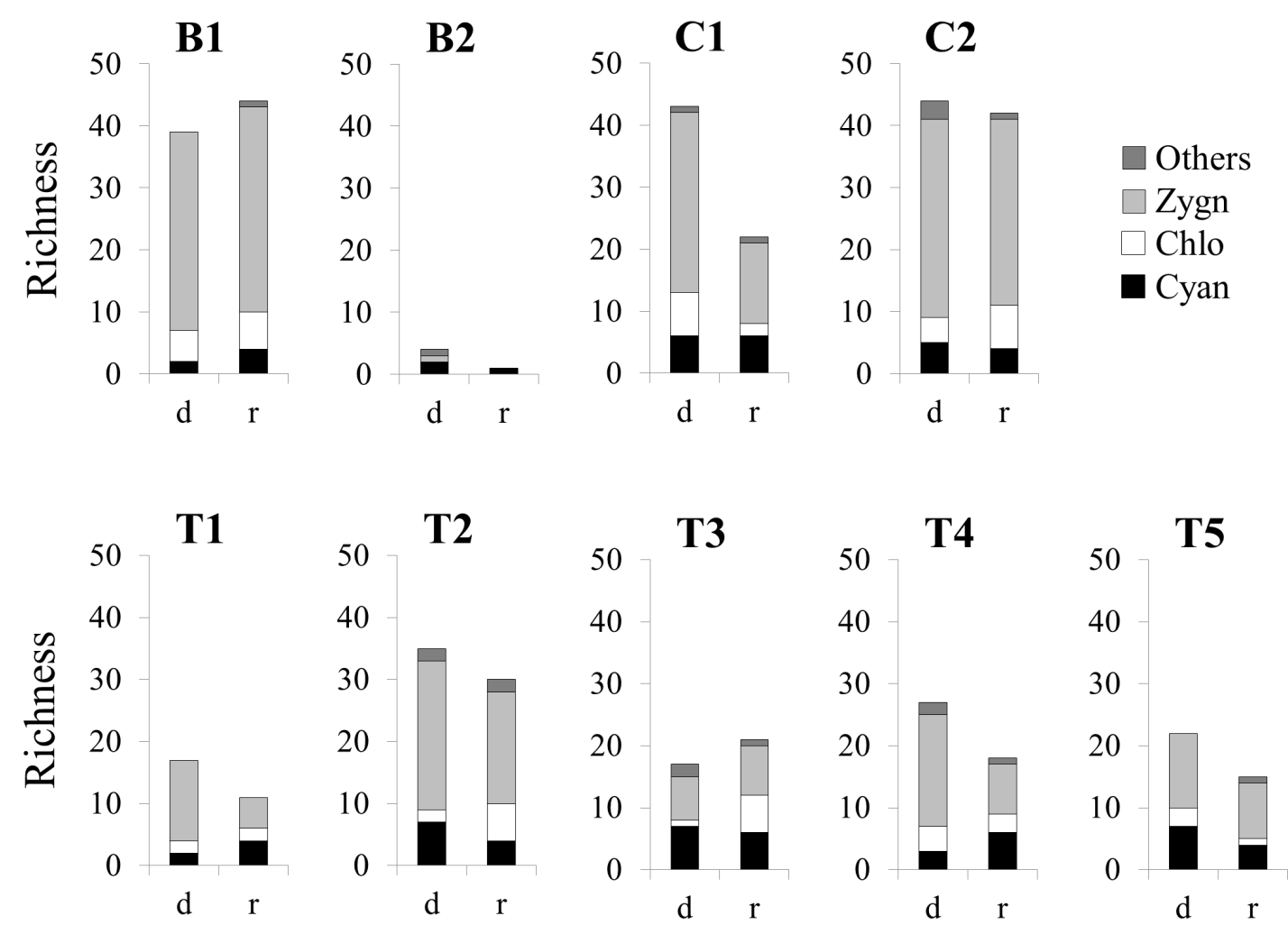

Figure 3. Species richness of soft-bodied benthic algae from streams in three protected areas in central Brazil, during dry (d) and rainy (r) seasons. The letters B, C and T represent, respectively, sites in Parque Nacional de Brasília, Parque Nacional da Chapada dos Veadeiros and Parque Estadual de Terra Ronca. Cyan $=$ Cyanobacteria, Chlo $=$ Chlorophyceae, Zygn $=$ Zygnematophyceae, Others $=$ other algal groups.

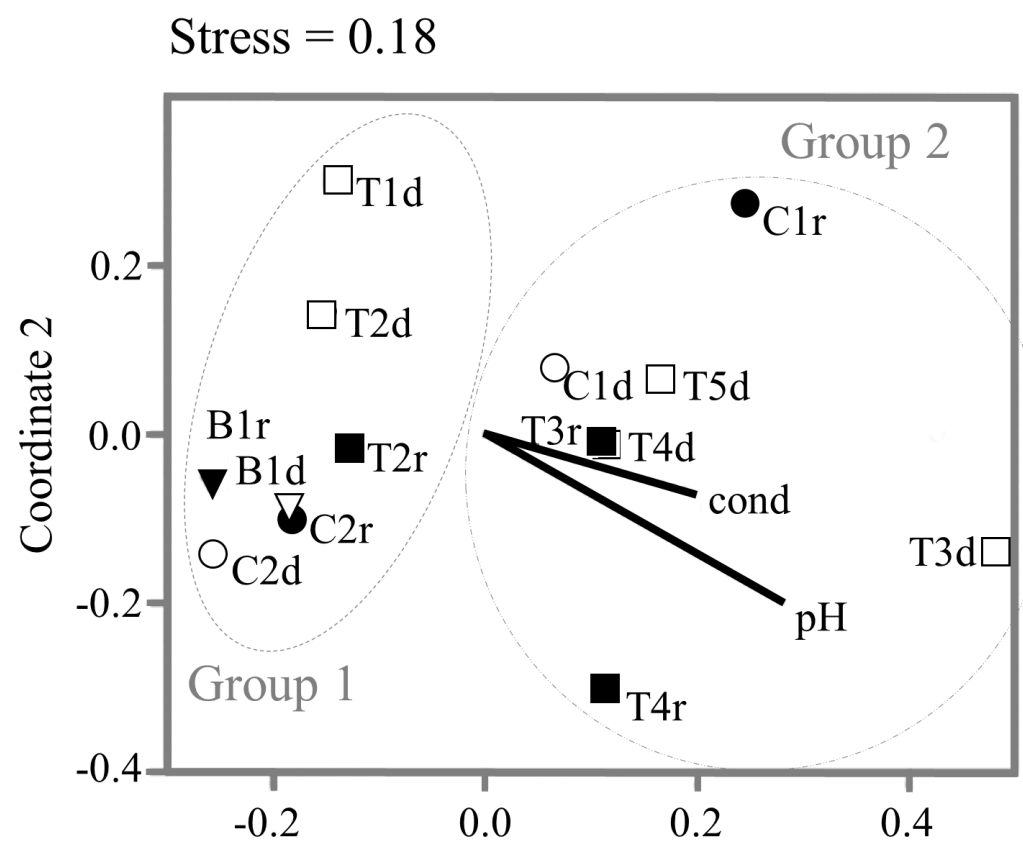

Coordinate 1

Figure 4. NMDS plot for soft-bodied benthic algae from streams in three protected areas in central Brazil (Dice Index). Inverted triangles = Parque Nacional de Brasília; circles = Parque Nacional da Chapada dos Veadeiros; squares = Parque Estadual de Terra Ronca. Open and filled symbols represent dry and rainy seasons, respectively. 
Table 3. Species list of soft-bodied benthic algae from streams, reported in three protected areas in central Brazil, during dry (white circles) and rainy seasons (black circles) (2012-2013). The letters B, C and T represent, respectively, sites in Parque Nacional de Brasília, Parque Nacional da Chapada dos Veadeiros and Parque Estadual de Terra Ronca. The numbers 1, 2, 3 and 4 mean, respectively, "rare", "common", "frequent" and "abundant".

\begin{tabular}{|c|c|c|c|c|c|c|c|c|c|}
\hline \multirow{2}{*}{ Taxa } & \multicolumn{9}{|c|}{ Sites } \\
\hline & B1 & B2 & C1 & $\mathrm{C2}$ & T1 & $\mathrm{T2}$ & T3 & T4 & T5 \\
\hline \multicolumn{10}{|l|}{ CYANOBACTERIA } \\
\hline Aff. Geitlerinema sp. & (1) & 4 & (1) & (1) & (2) & (1) (1) & (1) & \multirow[b]{2}{*}{ (2) } & \multirow[t]{2}{*}{ (2) (1) } \\
\hline Chamaesiphon sp. & & & & & & & & & \\
\hline Chroococcus sp. & & & & (1) & & & & & \\
\hline Hapalosiphon stuhlmannii Hieronymus & (2) (2) & & & (2) 2 & & (1) 2 & & & \\
\hline Johanseninema constrictum (Szafer) Hasler, Dvorák \& Poulícková & & & & & & & (1) & & (1) \\
\hline Lyngbya martensiana Meneguini ex Gomont & & & & & & & (1) & & \\
\hline Lyngbya sp. 1 & & & & & 2 & & (1) & & \\
\hline Lyngbya sp. 2 & & & & & & & (1) & & \\
\hline Lyngbya sp. 3 & & & & & 2 & & & & \\
\hline Lyngbya sp. 4 & & & & & 2 & & & & \\
\hline Lyngbya sp. 5 & & & & & & & & & (1) \\
\hline Merismopedia glauca (Ehrenberg) Kützing & & & & & & & (1) & & \\
\hline Nostocaceae sp. 1 & & & & & & & & (1) & (2) \\
\hline Nostocaceae sp. 2 & & & & & & & & & (2) \\
\hline Nostocaceae sp. 3 & (1) & & (1) & & & (1) & & & \\
\hline Nostocaceae sp. 4 & & & & (1) & & & & & \\
\hline Oscillatoria princeps Vaucher ex Gomont & & & & & & & (1) (2) & & \\
\hline Phormidioideae sp. 1 & & & & & & & (1) & & \\
\hline Phormidium sp. 1 & & & (1) (1) & & 2 & (1) & (1) 1 & (1) 1 & \\
\hline Phormidium sp. 2 & & & (1) & & & & & & 2 \\
\hline Phormidium sp. 3 & & & & & & & & (1) & (2) \\
\hline Pseudanabaena sp. 1 & & & & & & (2) & & & \\
\hline Pseudanabaenaceae sp. 1 & & (3) & (2) 2 & & (1) & & (1) (1) & (1) & \\
\hline Pseudanabaenaceae sp. 2 & & & (1) & & & & & & \\
\hline Rivularia aquatica De-Wildeman & & & & & & (2) 1 & & & \\
\hline Scytonema caldarium Setclhel & (2) (1) & (2) & & (2) (2) & & (2) 2 & & & \\
\hline Scytonema stuposum (Kützing) Bornet ex Bornet et Flahault & & & (1) 1 & & & & & (2) 1 & (1) (1) \\
\hline Stigonema ocellatum Thuret ex Bornet \& Flahault & & & & (2) 2 & & & & & \\
\hline Tapinothrix sp. & & & (1) 3 & & & & & & \\
\hline Tolypothrix distorta Kützing ex Bornet et Flahault & & & & & & & & 2 & (1) \\
\hline \multicolumn{10}{|l|}{ CHLOROPHYCEAE } \\
\hline Acutodesmus sp. & & & & & & & & (1) & \\
\hline Botryococcus sp. & & & & (1) & & & & & \\
\hline Bulbochaete sp. & (2) (1) & & (1) & (1) (2) & (1) 2 & (1) (1) & (1) & & \\
\hline Chaetophora sp. & & & (2) & & & & (1) (1) & (1) 1 & (2) \\
\hline Chlorophyta sp. & (1) & & & (1) & & & & & \\
\hline Klebsormidium scopulinum (Hazen) Ettl \& Gartner & (1) (1) & & (1) & (1) (1) & & (1) & (1) & (1) & \\
\hline Klebsormidium cf. subtile (Kützing) Mikhailyuk, Glaser, Holzinger \& Karsten & & & & & (1) & (1) & & & \\
\hline Microspora sp. & (1) (1) & & (1) (1) & (1) & & (1) & & & \\
\hline Microthamnion kuetzingianum Nägeli in Kützing & (1) (1) & & & & & & & & \\
\hline Oedogonium sp. 1 & & & & & 2 & (1) 2 & (1) & & (1) (2) \\
\hline Oedogonium sp. 2 & (2) (1) & & (1) & (1) (1) & & (1) & (1) & (2) 2 & (1) \\
\hline Oedogonium sp. 3 & & & (2) & & & & (1) & (1) & \\
\hline Oocystis sp. & & & (1) & (1) (1) & & & & & \\
\hline \multicolumn{10}{|l|}{ CHRYSOPHYCEAE } \\
\hline Dinobryon sp. & & & & (1) & & & & & \\
\hline Lagynion sp. & & & & (1) & & & & & \\
\hline \multicolumn{10}{|l|}{ CRYPTOPHYCEAE } \\
\hline Cryptomonas sp. & & & & & & (1) & & & \\
\hline DINOPHYCEAE & & & & & & & & & \\
\hline Dinophyta sp. 1 & & & & (1) & & & & & \\
\hline
\end{tabular}


Table 3. Cont.

\begin{tabular}{|c|c|c|c|c|c|c|c|c|c|}
\hline \multirow{2}{*}{ Taxa } & \multicolumn{9}{|c|}{ Sites } \\
\hline & B1 & B2 & C1 & C2 & T1 & $\mathrm{T2}$ & T3 & T4 & T5 \\
\hline \multicolumn{10}{|l|}{ EUGLENOPHYCEAE } \\
\hline Trachelomonas sp. 1 & & & & & & & & (1) & \\
\hline Euglena sp. 1 & & & & & & (1) (1) & & & (1) \\
\hline Euglena sp. 2 & & & & & & & (1) & (1) & \\
\hline Euglena sp. 3 & & & & & & & (1) & & \\
\hline Phacus sp. & & & (1) & & & & & & \\
\hline \multicolumn{10}{|l|}{ RHODOPHYTA } \\
\hline Batrachospermum sp. & & (2) & (1) & & & & (1) & 2 & \\
\hline \multicolumn{10}{|l|}{ XANTHOPHYCEAE } \\
\hline Heterothrix sp. & (1) & & & (2) & & (1) & & & \\
\hline \multicolumn{10}{|l|}{ ZYGNEMATOPHYCEAE } \\
\hline Actinotaenium cucurbita var. cucurbita f. minus (West et West) Teiling ex Croasdale & (1) (2) & & & (1) (1) & 2 & (1) (1) & (1) & (1) & (1) \\
\hline Actinotaenium cucurbita var. cucurbita f. latius (West et West) Teiling & & & & (1) (1) & & & & & \\
\hline Actinotaenium cucurbita var. rotundatum (Krieger) Teiling & & & (1) & (1) & & & & & 2 \\
\hline Actinotaenium cucurbitinum (Bisset) Teiling & & & (1) & & (1) & (1) & & & \\
\hline Actinotaenium curtum (Brébisson ex Ralfs) Teiling ex Růžička \& Pouzar & & & & & & & & & (1) \\
\hline Actinotaenium elongatum (Raciborski) Teiling & (1) & & (1) & (1) & & & & & \\
\hline Actinotaenium globosum (Bulnheim) Kurt Förster ex Compère & (1) (1) & & (1) & (1) (1) & & & & (1) & \\
\hline Actinotaenium wollei (West \& G.S.West) Teiling & & & (1) (1) & (1) & (1) & & & (1) & \\
\hline Bambusina brebissonii Kützing ex Kützing var. brasiliensis Kurt Förster & (1) & & & (1) (1) & & & & & \\
\hline Closterium closterioides (Ralfs) A.Louis \& Peeters & (1) & & (1) 1 & & (1) & & & & (1) \\
\hline Closterium dianae Ehrenberg ex Ralfs & & & (1) & & & & & & \\
\hline Closterium gracile Brébisson ex Ralfs & (1) (1) & & & & & (1) & & (1) & \\
\hline Closterium jenneri Ralfs & & & (1) (1) & & (1) & (1) & & (1) & (1) \\
\hline Closterium kuetzingii Brébisson & & & & & (1) & & & & \\
\hline Closterium moniliferum (Bory) Ehrenberg ex Ralfs & & & (1) & & & & (1) (1) & & (1) \\
\hline Closterim navicula (Brébisson) Lütkemüller & & (2) & & & (1) & (1) & & & \\
\hline Closterium parvulum Nägeli & (1) & & (1) & & & & & & \\
\hline Closterium pusillum Hantzsch & & & (1) & & & (1) & & & (1) \\
\hline Closterium regulare Brébisson & & & (1) & & & & & & \\
\hline Closterium setaceum Ehrenberg ex Ralfs & & & (1) & & & & & & \\
\hline Closterium cf. striolatum Ehrenberg ex Ralfs & & & & & (1) & & & & \\
\hline Closterium subulatum (Kützing) Brébisson & & & & & (1) & (1) & & & \\
\hline Cosmarium abbreviatum Raciborski var. minus (West \& G.S.West) Willi Krieger \& Gerloff & (1) (1) & & (1) & (1) (1) & & (1) & & (1) & (1) (1) \\
\hline Cosmarium decoratum West \& G.S.West & & & & (1) (1) & & & & & \\
\hline Cosmarium cf. decussiferum var. mediogranulatum Kurt Förster \& Eckert & & & (1) & & & & & & \\
\hline Cosmarium cf. luetzelburgii Kurt Förster & (1) (1) & & & & & & & & \\
\hline Cosmarium cf. subundulatum Wille & & & & & & & (1) & (1) & (1) \\
\hline Cosmarium cf. taxichondrum P.Lundell & & & (1) & & & & & & \\
\hline Cosmarium contractum O.Kirchner var. minutum (Delponte) Coesel & & (1) & (1) & & (1) & & (1) & & \\
\hline Cosmarium depressum (Nägeli) Lundell var. depressum f. minutum Heimerl & & (1) & (1) (1) & & (1) & (1) & & (1) & \\
\hline Cosmarium dimaziforme (Grönbl.) Scott \& Grönbl. var. undulatum Kurt Förster & & & (1) & & & & & & \\
\hline Cosmarium dimaziforme (Grönbl.) Scott \& Grönbl. var. concavum Kurt Förster & & & & (1) & & & & & \\
\hline Cosmarium granatum Brébisson ex Ralfs & & & & & & & (1) & (1) & 2 \\
\hline Cosmarium intermedium Delponte & (1) (1) & & & & & & & & \\
\hline Cosmarium laeve Rabenhorst var. acervatum Kurt Förster & & & & (1) (1) & & (1) & & & \\
\hline Cosmarium lundelli var. borgei & & & & & & & & (1) & (1) \\
\hline Cosmarium moniliforme f. elongatum West \& G.S.West & & & & & & (1) & & & \\
\hline Cosmarium pseudopyramidatum P.Lundell & (1) (1) & & & & & (1) & & (1) & (1) \\
\hline Cosmarium punctulatum Brébisson & & & & (1) (1) & & (1) & & & \\
\hline Cosmarium quadrum P.Lundell var. minus Nordstedt & & & & & & & (1) & (1) & (1) \\
\hline Cosmarium quinarium P.Lundell var. brasiliense Kurt Förster & (1) & & & & & & & & \\
\hline Cosmarium regnesi Reinsch & & & (1) & (1) & & & & & (1) \\
\hline Cosmarium sp. 1 & & & & (1) & & & & & \\
\hline Cosmarium sp. 2 & & & (2) & & & & & & \\
\hline
\end{tabular}


Table 3. Cont.

\begin{tabular}{|c|c|c|c|c|c|c|c|c|c|}
\hline \multirow{2}{*}{ Taxa } & \multicolumn{9}{|c|}{ Sites } \\
\hline & B1 & B2 & C1 & C2 & T1 & T2 & T3 & T4 & T5 \\
\hline Cosmarium sp. 3 & & & & (1) & & & & & \\
\hline Cosmarium subspeciosum var. subspeciosum Nordstedt & & & & & & & (1) & (1) & (1) \\
\hline Cosmarium subtumidum Nordstedt & (1) (1) & & (1) & & (1) & (1) & & & \\
\hline Cosmarium trilobulatum Reinsch var. abscissum (Schmidle) Willi Krieger \& Gerloff & (1) (1) & & & & & (1) (1) & & & \\
\hline Cosmarium vitiosum Scott \& Grönblad & (1) 1 & & & & & & & & \\
\hline Cylindrocystis brebissonii (Ralfs) De Bary & (1) 1 & & & & (1) & 0 & & & \\
\hline Cylindrocystis obesa West \& G.S.West & & & (1) & & & & & & \\
\hline Desmidium graciliceps (Nordstedt) Lagerheim & & & & (1) & & & & & \\
\hline Desmidium grevillei (Kützing ex Ralfs) De Bary & & & & & & 2 & & & \\
\hline Euastrum arciferum Borge & (1) 1 & & & & & & & & \\
\hline Euastrum brasiliense Borge & (1) & & & (1) & & & & & \\
\hline Euastrum cf. angolense (West \& G.S.West) Willi Krieger var. brasiliense Willi Krieger & (1) (1) & & & (1) & & & & & \\
\hline Euastrum cf. bilobum Lütkemüller & (1) (1) & & & & & & & & \\
\hline Euastrum cf. cornubiense West \& G.S.West & & & & & (1) & & & & \\
\hline Euastrum crassangulatum Børgesen & & & & (1) & & & & & \\
\hline Euastrum croasdaleae Gronblad var. incrassatum Kurt Förster & (1) 1 & & & (1) (1) & & (1) & & & \\
\hline Euastrum evolutum var. trilobum (W.R.Taylor) W.Krieger & (1) & & & (1) & & & & & \\
\hline Euastrum humbertii P.Bourrelly var. brasiliense W.Krieger & (1) 1 & & & (1) & & & & & \\
\hline Euastrum inusitatum Kurt Förster & (1) & & & & & (1) & & & \\
\hline Euastrum pirassunungae Borge & & & & (1) & & & & & \\
\hline Euastrum rectangulare Fritsch \& M.F.Rich & & & & (1) & & & & & \\
\hline Euastrum sublobatum Brébisson ex Ralfs & & & & (1) (1) & & & & & \\
\hline Euastrum subtrilobulatum var. gibbosum Kurt Förster \& F.Eckert & (1) & & & (1) & & & & & \\
\hline Euastrum sp.1 & (1) 1 & & (1) & & & (1) & & & \\
\hline Euastrum sp. 2 & & & & & & (1) & (1) & (1) & \\
\hline Gonatozygon pilosum Wolle & (1) 2 & & & (1) & & & & & \\
\hline Haplotaenium minutum (Ralfs) Bando & (1) (1) & & (1) & (1) (1) & (1) & & & (1) & \\
\hline Hyalotheca dissiliens Brébisson ex Ralfs & & & (1) & (1) & & & & & \\
\hline Mesotaenium sp. & & & & (1) (1) & & (1) 1 & (1) & & \\
\hline Micrasterias arcuata Bailey var. subpinnatifida West \& G.S.West & (1) (1) & & & (1) & & (1) & & & \\
\hline Micrasterias arcuata Bailey var. robusta Borge & & & & (1) & & & & & \\
\hline Micrasterias depauperata Nordstedt var. kitchelii (Wolle) West \& West & (1) & & & & & (1) & & & \\
\hline Micrasterias rotata Ralfs & & & (1) & & & & & & \\
\hline Micrasterias truncata Nordstedt var. excavata Nordstedt & (1) & & & & & & & & \\
\hline Mougeotia sp. 1 & & & (2) 1 & (1) (1) & & (1) (2) & 3 & (2) & (2) 2 \\
\hline Mougeotia sp. 2 & & & (1) & & (2) & (2) & & & \\
\hline Mougeotia sp. 3 & (2) 1 & & (1) & (1) (1) & (3) & (2) (1) & (1) & (2) (1) & (1) \\
\hline Netrium digitus (Brébisson ex Ralfs) Itzigsohn \& Rothe & (1) 1 & & (1) & & & & & & \\
\hline Pleurotaenium ehrenbergii (Ralfs) Delponte & & & (1) & & & & & & \\
\hline Spirogyra sp. 1 & & & & & & & (4) (1) & (2) & \\
\hline Spirogyra sp. 2 & & & & & & (1) & & (2) & \\
\hline Spirogyra sp. 3 & (1) (1) & & & & & & & & \\
\hline Spirotaenia cf. condensata Brébisson & & & (1) & & & & & & \\
\hline Spondylosium desmidiforme (Borge) West \& West & & & & & (1) & & & & \\
\hline Staurastrum hystrix Ralfs var. floridense Scott \& Gronblad & (1) 1 & & & (1) (1) & & & & & \\
\hline Staurastrum cf. margaritaceum Meneghini ex Ralfs & & & & & & & & (1) & (1) \\
\hline Staurastrum orbiculare Meneghini ex Ralfs & (1) (1) & & & (1) (1) & & (1) & & & \\
\hline Staurastrum cf. proboscideum Archer & (1) 1 & & & & & & & & \\
\hline Staurastrum quadrangulare Brébisson & & & & (1) & & (1) & & & \\
\hline Staurastrum sp. 1 & & & (1) & & & & & & \\
\hline Staurastrum sp. 2 & & & & & & & & (1) & \\
\hline Staurodesmus convergens (Ehrenberg ex Ralfs) Teiling var. laportei Teiling & & & & & & & (1) & & \\
\hline Staurodesmus incus (Hassal ex Ralfs) Teiling & & & & (1) & & & & & \\
\hline Staurodesmus dickiei (Ralfs) S.Lillieroth & (1) & & (1) & (1) & & & & & \\
\hline Staurodesmus spencerianus (Nordstedt) Teiling & & & & & & (1) (1) & & & \\
\hline
\end{tabular}


Table 3. Cont.

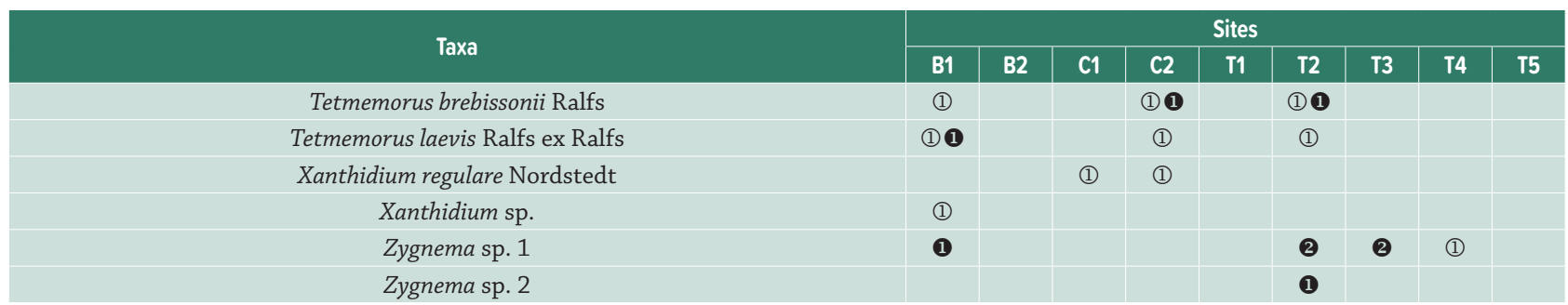

\section{Discussion}

This study provides new information about the limnological and algal properties of pristine streams in central Brazil. All streams have in common very low nutrient concentrations, in accordance with the literature about undisturbed Cerrado basins (e.g. Markewitz et al. 2006; Fonseca \& Mendonça-Galvão 2014), despite the differences in their $\mathrm{pH}$ and electrical conductivity (EC). The relatively higher EC observed here for streams connected to caves (PETeR) indicates the presence of other dissolved ions in the water besides nutrients such as phosphorus and nitrogen, which were around the detection limits. Compared with pristine karst systems around the world, where EC is generally above $400 \mu \mathrm{S} \mathrm{cm}-1$ (e.g. Righi-Cavallaro et al. 2010; Vilenica et al. 2017), it is noticeable, however, that even the EC values in streams connected to caves were not very high. The headwaters of PETeR's streams are located in the hills of Serra Geral de Goiás. They flow around $20 \mathrm{~km}$ westwards through sandstone until they reach the limestone outcrop (Faquim et al. 2017). Such proximity may buffer the effects of rock dissolution on the water chemical variables. Sites T1 and $\mathrm{T} 2$, for instance, showed slightly acidic $\mathrm{pH}$, with very low EC $(<10 \mu \mathrm{S} \mathrm{cm}-1)$, similar to sites located in the other protected areas (PNB and PNCV).

The Cerrado region experiences strong seasonality (dry versus rainy season), and rainfall is a relevant water input to local lotic systems, especially low order ones (Markewitz et al. 2006). In the studied streams, seasonality significantly affected depth and water velocity, which are important physical variables influencing benthic communities, since physical disturbance promoted by higher flow velocity during the high rainfall phases may inhibit growth and maintenance for most taxa (Righi-Cavallaro et al. 2010). A similar pattern was reported for macroalgal communities in southeastern Brazil (Branco \& Necchi Jr. 1997). In the present study, algal richness was not affected by seasonality; however, it was more difficult to reach the 400 individuals in most samples collected during the rainy season, suggesting that algal production is hindered during rainy periods.

Higher richness was reported in particular when macrophytes were present (e.g. B1, C1, C2 and T2). Aquatic plants, especially submerged ones with complex architecture (e.g. Sphagnum, Utricularia), contribute to habitat heterogeneity, which is an important factor for the maintenance of periphyton richness (Algarte et al. 2017). In this context, site $\mathrm{C} 2$, the richest one, had the "best of all worlds"; it presented abundant macrophyte cover on the rocky bed, in an unshaded area of "crystal clear" waters. Since light availability is also recognized as a determinant abiotic factor for algal communities (Tonetto et al. 2015), algal development at site $C 2$ was positively influenced by the combination of light and macrophyte cover in abundance.

The similarity among sites was relatively low, as indicated by the Whittaker Index of beta diversity $(\beta \mathrm{w}=$ 5.33). According to McCune \& Grace (2002, p. 31), "values of $\beta \mathrm{w}<1$ are rather low and $\beta \mathrm{w}>5$ can be considered high". Branco et al. (2008b) and Tonetto et al. (2015) also described low similarity in macroalgal communities from southeastern/southern Brazil, with most taxa restricted to a single sampling site. In a dataset composed of almost 500 temperate streams (New York State and Austria), Rott \& Wehr (2016) also reported few widely distributed taxa, without any ubiquitous ones.

The species composition among SB algae ranged from typical acidophilic taxa to taxa associated with alkaline waters. The most common group in terms of species richness, Zygnematophyceae, is known for its ecological preference for oligo-mesotrophic waters, with slightly low pH (Coesel \& Meesters 2007). For this reason, these algae are frequently observed in Cerrado waters (Estrela et al. 2011; Dunck et al. 2013). Fonseca et al. (2018) reported this group as the richest one among non-diatom periphytic algae in Cerrado wetlands. Some European floras have indicated many acidophilic taxa among Zygnematophyceae, and some of them were reported in our streams, highlighting here Cylindrocystis brebissonii, Closterium closterioides, Tetmemorus laevis, Micrasterias spp., Euastrum spp. (Štastný 2009). The presence of Sphagnum banks (e.g. site B1) as substrate, and the typical acidic environment created by this plant, certainly favored these occurrences (Coesel \& Meesters 2007).

Cyanobacteria, the second group in terms of species richness, have also been reported as an important component in Cerrado acidic wetlands (Fonseca et al. 2018), represented mainly by branched heterocytous taxa (e.g. Scytonema, Stigonema, Hapalosiphon), which were commonly reported here as well, under similar ecological conditions. In the sites with relatively higher $\mathrm{pH}$ and electrical conductivity, however, there were some exclusive taxa belonging to 
the orders Oscillatorialles (Oscillatoria princeps, Lyngbya martesiana) or Nostocales (Tolypothrix distorta) not usually reported in Cerrado waters.

\section{Some rare or interesting species}

We reported the cyanobacterium Rivularia aquatica for the first time in Brazil (Menezes et al. 2015). The identification is according to Komárek (2013, p. 308), which describes this species as pantropical. Up to now, there were only two species cited in Brazil (State of São Paulo, southeastern region), $R$. atra Roth and $R$. cf. beccariana (De Notaris) Bornet et Flahault (Sant'Anna et al. 2011). The former, however, is a marine species, while the latter presents thinner trichomes when compared to $R$. aquatica.

Tolypothrix distorta (Cyanobacteria) had already been reported in Brazil only for the southeastern/southern regions (Branco et al. 2001; 2009; Krupek et al. 2013; Menezes et al. 2015), and was here cited for the first time in central Brazil. In Europe, Rott \& Schneider (2014) reported the species at $\mathrm{pH}$ ranging from 6.91 (Norway) to 8.02 (Austria). According to Komárek (2013, p. 439), however, it is "usually in strictly alkaline, stagnant or slowly streaming waters". This explains why this taxon has not been mentioned in previous studies on Cyanobacteria from Cerrado acidic environments, where genera such as Stigonema, Hapalosiphon and Scytonema are more common (Senna \& Ferreira 1987; Fonseca et al. 2018). The environmental conditions found in PETeR, on the other hand, favor the occurrence of such alkaliphilic taxa. Branco et al. (2009) reported it at $\mathrm{pH}=7.21-7.45$, and electrical conductivity $=63.8-73.4 \mu \mathrm{S} \mathrm{cm}{ }^{-1}$.

The genus Microthamnion is often reported from unpolluted, neutral to acidic fresh waters (Bicudo \& Menezes 2006; Guiry 2017), sometimes with wet carpets of moss (John 2003). This agrees with conditions in Bananal stream (B1) in the present study, where it was recorded in both dry and rainy seasons. In Brazil, the only reference for the genus is Bicudo \& Menezes (2006), in which the occurrence of $M$. kuetzingianum in the State of São Paulo is mentioned.

In summary, soft-bodied algal community structure varied significantly among sites, but not between dry and rainy seasons. There were somewhat lower abundances during the rainy season, likely due to faster currents during this period. The relatively higher $\mathrm{pH}$ and conductivity values in the sites connected to caves in Parque Estadual de Terra Ronca seemed to be an important factor driving differences in species composition among the studied sites. Some alkaliphilic taxa were reported only at sites near the caves, highlighting the cyanobacterium Tolypothrix distorta, while acidophilic taxa (e.g. Cyanobacteria Scytonema caldarium, Stigonema ocellatum, Hapalosiphon stuhlmannii; Zygnematophyceae Cylindrocystis brebissonii, Closterium closterioides, Tetmemorus laevis, Micrasterias spp., Euastrum spp.) were more frequent at the other sites, regardless of the protected area, especially when macrophytes were present.

\section{Acknowledgements}

We thank to CNPQ for the research grant (ID numbers 563134/2010-0 and 457431/2012-1); ICMBIO and SEMARH (Goiás) for the support in the protected areas; Universidade Católica de Brasília for the scholarship granted to LMF and for chemical analyses; Dr. Célia Leite Sant'Anna (IBT-SP) for her help in cyanobacterial identification; our colleagues from Grupo de Estudos de Ecossistemas Aquáticos (GEEA) and the ComCerrado network involved in field and laboratory work.

\section{References}

Algarte VM, Siqueira T, Landeiro VL, et al. 2017. Main predictors of periphyton species richness depend on adherence strategy and cell size. PLOS ONE 12(7): e0181720. doi: 10.1371/journal.pone.0181720

Alvares CA, Stape JL, Sentelhas PC, Gonçalves JLM, Sparovek G. 2014. Köppen's climate classification map for Brazil. Meteorologische Zeitschrift 22: 711-728.

APHA 2005. Standard methods for the examination of water and wastewater. 21st. edn. Washington, American Public Health Association.

Bicudo CEM, Menezes M. 2006. Gêneros de algas de águas continentais do Brasil (Chave para identificação e descrições). 2nd. edn. São Carlos, RiMa Editora.

Branco CCZ, Emed RG, Branco LHZ, Necchi Jr. O. 2008a. Macroalgas de riachos da Floresta Nacional de Irati, região centro-sul do Estado do Paraná, Sul do Brasil. Acta Botanica Brasilica 22: 437-451.

Branco CCZ, Krupek RA, Peres CK. 2008b. Seasonality of macroalgal communities in a subtropical drainage basin in Paraná state, southern Brazil. Brazilian Journal of Biology 68: 741-749.

Branco CCZ, Krupek RA, Peres CK. 2009. Distribution of stream macroalgal communities from the mid-western region of Paraná State, southern Brazil: importance of local scale variation. Brazilian Archives of Biology and Technology 52: 379-386.

Branco LHZ, Necchi Jr. O. 1997. Seasonality of macroalgae in three tropical drainage basins in São Paulo State, southeastern Brazil. Archiv für Hydrobiologie 141: 75-91.

Branco LHZ, Necchi Jr. O, Branco CCZ. 2001. Ecological distribution of Cyanophyceae in lotic ecosystems of São Paulo State. Revista Brasileira de Botânica 24: 99-108.

Clarke KR. 1993. Non-parametric multivariate analysis of changes in community structure. Australian Journal of Ecology 18: 117-143.

Coesel PFM, Meesters KJ. 2007. Desmids of the Lowlands: Mesotaeniaceae and Desmidiaceae of the European Lowlands. Zeist, KNNV Publishing.

Dunck B, Nogueira IS, Felisberto S. 2013. Distribution of periphytic algae in wetlands (Palm swamps, Cerrado), Brazil. Brazilian Journal of Biology 73: 331-346.

Estrela LMB, Fonseca BM, Bicudo CEM. 2011. Desmídias perifíticas de cinco lagoas do Distrito Federal, Brasil: I - Gênero Cosmarium Corda ex Ralfs. Hoehnea 38: 527-552.

Faquim ACS, Zancopé MHC, Cherem LFS. 2017. Potencial de transferência de sedimentos das bacias contribuintes do sistema cárstico Terra Ronca. Boletim Goiano de Geografia 37: 448-465.

Fetscher AE, Stancheva R, Kociolek JP, et al. 2014. Development and comparison of stream indices of biotic integrity using diatoms vs. non-diatom algae vs. a combination. Journal of Applied Phycology 26: $433-450$.

Fonseca BM, Mendonça-Galvão L, Padovesi-Fonseca C, Abreu LM, Fernandes ACM. 2014. Nutrient baselines of Cerrado low-order streams: comparing natural and impacted sites in the central Brazil. Environmental Monitoring and Assessment 186: 19-33.

Fonseca BM, Mendonça-Galvão L. 2014. Pristine aquatic systems in a Long Term Ecological Research (LTER) site of the Brazilian Cerrado. Environmental Monitoring and Assessment 186: 8683-8695. 
Fonseca BM, Mendonça-Galvão L, Sousa FDR, et al. 2018. Biodiversity in pristine wetlands of central Brazil: a multi-taxonomic approach. Wetlands 38: 145-156.

Förster K. 1964. Desmidiaceen aus Brasilien. 2. Teil: Bahia, Goyaz, Piauhy und Nord-Brasilien. Hydrobiologia XXIII: 321-505.

França AA, Dunck B, Rodrigues L, Fonseca BM, Felisberto SA. 2017. Periphytic diatoms (Bacillariophyta) in streams from three Conservation Units of central Brazil: Pinnularia Ehrenberg. Hoehnea 44: 524-538

Garraza GG, Burdman MD, Mataloni G. 2019. Desmids (Zygnematophyceae, Streptophyta) community drivers and potential as a monitoring tool in South American peat bogs. Hydrobiologia 833: 125-141.

Guiry MD. 2017. AlgaeBase. In: Guiry MD, Guiry GM. AlgaeBase. Galway, World-wide electronic publication, National University of Ireland. http://www.algaebase.org. 26 Jul. 2017.

Hammer Ø, Harper DAT, Ryan PD. 2001. PAST: Paleontological statistics software package for education and data analysis. Paleontologia Eletronica 4: 1-9.

ICMBIO - Instituto Chico Mendes de Conservação da Biodiversidade. 2016. Unidades de Conservação. http://www.icmbio.gov.br/portal/ unidadesdeconservacao/biomas-brasileiros. 02 Jul. 2016.

John DM. 2003. Filamentous and Plantlike Green Algae. In: Wehr JD, Sheath RG. (eds.) Freshwater Algae of North America: Ecology and classification. San Diego, Academic Press. p. 311-352.

Kadlubowska JZ. 1984. Conjugatophyceae I, Chlorophyta VIII., Zygnematales. In: Ettl H, Gerloff J, Heynig H, Mollenhauer D. (eds.) Süßwasserflora von Mitteleuropa 16. Stuttgart, Gustav Fisher Verlag. p.1-532.

Kelly MG, King L, Jones RI, Barker PA, Jamieson BJ. 2008. Validation of diatoms as proxies for phytobenthos when assessing ecological status in lakes. Hydrobiologia 610: 125-129.

Komárek J. 2013. Cyanoprokaryota 3. Teil / 3rd part: Heterocytous Genera. In: Büdel B, Krienitz L, Gärtner G, Krienitz L, Schagerl M. (eds.) Süßwasserflora von Mitteleuropa. Berlin, Springer Spektrum. p. 1-1031.

Komárek J, Anagnostidis K. 2005. Cyanoprokaryota 2. Teil / 2nd part: Oscillatoriales. In: Büdel B, Krienitz L, Gärtner G, Schagerl M. (eds.) Süßwasserflora von Mitteleuropa. München, Spektrum Akademischer Verlag. p. 1-759.

Krupek RA, Branco CCZ, Peres CK. 2013. Microhabitat de Tolypothrix distorta Kütz. ex Bornet \& Flahault (Microchaetaceae, Cyanophyta) em dois riachos da região Centro-Sul do Estado do Paraná, Brasil. Hoehnea 40: 595-600.

Lenzenweger R. 1996. Desmidiaceeflora von Österreich. Teil 1. Bibliotheca Phycologica 101: 1-162.

Lindstrøm E-A, Johansen SW, Saloranta T. 2004. Periphyton in running waters - long-term studies of natural variation. Hydrobiologia 521: 63-86.

Markewitz D, Resende JCF, Parron L, et al. 2006. Dissolved rainfall inputs and streamwater outputs in an undisturbed watershed on highly weathered soils in the Brazilian cerrado. Hydrological Processes 20: 2615-2639.

McCune B, Grace JB. 2002. Analysis of ecological communities. Oregon, MjM Software Design.

Menezes M, Bicudo CEM, Moura CWN, et al. 2015. Update of the Brazilian floristic list of Algae and Cyanobacteria. Rodriguésia 66: 1-16.

Mutinová PT, Neustupa J, Bevilacqua S, Terlizzi A. 2016. Host specificity of epiphytic diatom (Bacillariophyceae) and desmid (Desmidiales) communities. Aquatic Ecology 50: 697-709.

Necchi Jr. O. 2016. An overview of river Algae. In: Necchi Jr. O. (ed.) River Algae. [s.1.], Springer. p. 1-4.

Necchi Jr. O, Branco LHZ, Spezamiglio DN. 2008. Distribuição ecológica de comunidades de macroalgas de ambientes lóticos do Parque Nacional de Itatiaia (RJ, MG), Brasil. Revista Brasileira de Botânica 31: 135-145.

Poikane S, Martyn K, Cantonati M. 2016. Benthic algal assessment of ecological status in European lakes and rivers: Challenges and opportunities. Science of the Total Environment 568: 603-613.

Ramanathan KR. 1964. Ulotrichales. New Delhi, Indian Council of Agricultural Research.
Righi-Cavallaro KO, Roche KF, Froehlich O, Cavallaro MR. 2010. Structure of macroinvertebrate communities in riffles of a Neotropical karst stream in the wet and dry seasons. Acta Limnologica Brasiliensia 22: 306-316

Rott E, Schneider SC. 2014. A comparison of ecological optima of soft-bodied benthic algae in Norwegian and Austrian rivers and consequences for river monitoring in Europe. Science of the Total Environment 475: 180-186.

Rott E, Wehr JD. 2016. The spatio-temporal development of macroalgae in river. In: Necchi Jr. O. (ed.) River Algae. [s.l.], Springer. p. 159-195.

Růžička J. 1981. Die Desmidiaceen Mitteleuropas. Band 1, 1. Stuttgart, Schweizerbart'sche Verlagsbuchhandlung.

Salomoni SE, Rocha O, Hermany G, Lobo EA. 2011. Application of water quality biological indices using diatoms as bioindicators in the Gravatai river, RS, Brazil. Brazilian Journal of Biology 71: 949-959.

Sant'Anna CL, Branco LHZ, Gama Jr. WA, Werner VR. 2011. Lista de Cyanobacteria do Estado de São Paulo. Biota Neotropica 11: 1-41.

Schneider SC. 2015. Greener rivers in a changing climate? Effects of climate and hydrological regime on benthic algal assemblages in pristine streams. Limnologica 55: 21-32.

Schneider SC, Lindstrøm E-A. 2009. Bioindication in Norwegian rivers using non-diatomaceous benthic algae: The acidification index periphyton (AIP). Ecological Indicators 9: 1206-1211.

Schneider SC, Lindstrøm E-A. 2011. The periphyton index of trophic status PIT: a new eutrophication metric based on non-diatomaceous benthic algae in Nordic rivers. Hydrobiologia 665: 143-155.

SEMAD - Secretaria de Estado de Meio Ambiente e Desenvolvimento Sustentável. 2018. Parque Estadual de Terra Ronca - PETeR. http:// www.meioambiente.go.gov.br/component/content/article/118-meioambiente/unidades-de-conserva\%C3\%A7\%C3\%A3o/1127-parqueestadual-de-terra-ronca-peter.html?Itemid=101. $24 \mathrm{Jul} .2019$.

Senna PAC, Ferreira LV. 1987. Nostocophyceae (Cyanophyceae) da Fazenda Água Limpa, Distrito Federal, Brazil, 2: Famílias Scytonemataceae e Stigonemataceae. Rickia 14: 7-19.

Silva FAM, Assad ED, Evangelista BA. 2008. Caracterização climática do bioma Cerrado, In: Sano SM, Almeida SMP, Ribeiro JF. (eds.) Cerrado: Ecologia e Flora. Brasília, Embrapa Informação Tecnológica. p. 69-87.

Stancheva R, Sheath RG. 2016. Benthic soft-bodied algae as bioindicators of stream water quality. Knowledge and Management of Aquatic Ecosystems 417: 15. doi: 10.1051/kmae/2016002

Stancheva R, Sheath RG, Read BA, et al. 2013. Nitrogen-fixing cyanobacteria (free-living and diatom endosymbionts): their use in southern California stream bioassessment. Hydrobiologia 720: 111-127.

Štastný J. 2009. The desmids of the Swamp Nature Reserve (North Bohemia, Czech Republic) and a small neighbouring bog: species composition and ecological condition of both sites. Fottea 9: 135-148.

Taras MJ. 1950. Phenoldisulfonic acid for determining nitrate in waterphotometric study. Analytical Chemistry 20: 1020-1022.

Teixeira AMC, Pinto JRR, Amaral AG, Munhoz CBR. 2017. Angiosperm species of "Cerrado" sensu stricto in Terra Ronca State Park, Brazil: floristics, phytogeography and conservation. Brazilian Journal of Botany 40: 225-234.

Thomas KE, Hall RI, Scrimgeour GJ. 2015. Relations between water physicochemistry and benthic algal communities in a northern Canadian watershed: defining reference conditions using multiple descriptors of community structure. Environmental Monitoring and Assessment 187: 564. doi: 10.1007/s10661-015-4778-x

Tonetto AF, Auricchio MR, Pezzatto LC, Peres CK. 2018. Macroalgas de riachos na Serra do Japi, sudeste do Estado de São Paulo, Brasil. Hoehnea 45: 616-628.

Tonetto AF, Hirata RT, Peres CK, Branco CCZ. 2015. Spatial and temporal distribution of stream macroalgae in a tropical river basin. Biota Neotropica 15: 1-8.

Valderrama JC. 1981. The simultaneous analysis of total nitrogen and phosphorus in natural waters. Marine Chemistry 10: 109-122.

Vilenica M, Stanković VM, Sartori M, Kučinić M, Mihaljević Z. 2017. Environmental factors affecting mayfly assemblages in tufa-depositing habitats of the Dinaric Karst. Knowledge and Management of Aquatic Ecosystems 418(14). doi: 0.1051/kmae/2017005 